University of Nebraska - Lincoln

DigitalCommons@University of Nebraska - Lincoln

\title{
Development of Single Nucleotide Polymorphism Markers for the Wheat Curl Mite Resistance Gene Cmc4
}

\author{
Jixin Zhao \\ Northwest A\&F University \& Kansas State University \\ Nader R. Abdelsalam \\ Kansas State University \& Alexandria University \\ Luaay Khalaf \\ Kansas State University \& University of Baghdad \\ Wen-Po Chuang \\ Kansas State University \& National Taiwan University \\ Lanfei Zhao
}

See next page for additional authors

Follow this and additional works at: https://digitalcommons.unl.edu/usdaarsfacpub

Part of the Agriculture Commons

Zhao, Jixin; Abdelsalam, Nader R.; Khalaf, Luaay; Chuang, Wen-Po; Zhao, Lanfei; Smith, C. Michael; Carver, Brett; and Bai, Guihua, "Development of Single Nucleotide Polymorphism Markers for the Wheat Curl Mite Resistance Gene Cmc4" (2019). Publications from USDA-ARS / UNL Faculty. 2190.

https://digitalcommons.unl.edu/usdaarsfacpub/2190

This Article is brought to you for free and open access by the U.S. Department of Agriculture: Agricultural Research Service, Lincoln, Nebraska at DigitalCommons@University of Nebraska - Lincoln. It has been accepted for inclusion in Publications from USDA-ARS / UNL Faculty by an authorized administrator of DigitalCommons@University of Nebraska - Lincoln. 


\section{Authors}

Jixin Zhao, Nader R. Abdelsalam, Luaay Khalaf, Wen-Po Chuang, Lanfei Zhao, C. Michael Smith, Brett Carver, and Guihua Bai 


\title{
Development of Single Nucleotide Polymorphism Markers for the Wheat Curl Mite Resistance Gene Cmc4
}

\author{
Jixin Zhao, Nader R. Abdelsalam, Luaay Khalaf, Wen-Po Chuang, Lanfei Zhao, C. Michael Smith, \\ Brett Carver, and Guihua Bai`
}

\begin{abstract}
Wheat curl mite (Aceria tosichella Keifer) is an important wheat (Triticum aestivum L. em. Thell.) pest in many wheat-growing regions worldwide. Mite feeding damage not only directly affects wheat yield, but $A$. tosichella also transmits Wheat streak mosaic virus (WSMV). Wheat resistance to $A$. tosichella, therefore, helps control WSMV. OK05312 (PI 670019) is an advanced breeding line released from Oklahoma that shows a high level of $A$. tosichella resistance. To map the gene(s) conditioning wheat resistance to $A$. tosichella in OK05312, a genetic linkage map was constructed using single nucleotide polymorphism (SNP) markers derived from genotyping-by-sequencing (GBS) and a population of 186 recombinant inbred lines (RILs) from the cross 'Jerry' (PI 632433)/OK05312. Seedlings of both parents and the RIL population were infested by $A$. tosichella Biotype 1 in greenhouse experiments. One major quantitative trait locus was identified on the short arm of chromosome 6D, which corresponds to the previously reported gene $\mathrm{Cmc} 4$ for $A$. tosichella resistance. This gene explained up to $71 \%$ of the phenotypic variation and was delimited in a 1.7-Mb ( 3.3-cM) region by SNPs $370 S N P 7523$ and 370SNP1639. We successfully converted 12 GBS-SNPs into Kompetitive allele specific polymerase chain reaction (KASP) markers. Two of them tightly linked to $\mathrm{Cmc} 4$ were validated to be highly diagnostic in a US winter wheat population and can be used for marker-assisted breeding for incorporation of $\mathrm{Cmc} 4$ into new wheat cultivars.
\end{abstract}

J. Zhao, College of Agronomy, Northwest A\&F Univ., No. 3 Taicheng Rd, Yangling 712100, Shaanxi Province, China; J. Zhao, N.R. Abdelsalam, L. Zhao, and G. Bai, Dep. of Agronomy, Kansas State Univ., 2004 Throckmorton Hall, Manhattan KS 66506; N.R. Abdelsalam, Agricultural Botany Dep., Faculty of Agriculture, Saba Basha, Alexandria Univ., Alexandria 21531, Egypt; L. Khalaf, W.-P. Chuang, and C.M. Smith, Dep. of Entomology, Kansas State Univ., 123 Waters Hall, Manhattan KS 66506; L. Khalaf, Dep. of Plant Protection, College of Agriculture, Univ. of Baghdad, Al-Jadriyah, Baghdad, Iraq; W.-P. Chuang, Dep. of Agronomy, National Taiwan Univ., No. 1, Sec. 4, Roosevelt Rd., Taipei 10617, Taiwan; B. Carver, Dep. of Plant and Soil Sciences, Oklahoma State Univ., 371 Agricultural Hall, Stillwater, OK 74078; G. Bai, USDA, Hard Winter Wheat Genetics Research Unit, 4008 Throckmorton Hall, Manhattan KS 66506. Received 20 Nov. 2018. Accepted 4 Mar. 2019. *Corresponding author (guihua.bai@usda.gov). Assigned to Associate Editor Shuyu Liu.

Abbreviations: BLAST, Basic Local Alignment Search Tool; ELISA, enzyme-linked immunosorbent assay; GBS, genotyping-by-sequencing; KASP, Kompetitive allele specific polymerase chain reaction; LRR, leucine-rich repeat; MAS, marker-assisted selection; NBS, nucleotide binding site; PCR, polymerase chain reaction; QTL, quantitative trait locus; RFLP, restriction fragment length polymorphism; RIL, recombinant inbred line; SNP, single nucleotide polymorphism; SSR, simple sequence repeats; TIR, Toll interleukin-1 receptor; UNEAK, Universal NetworkEnabled Analysis Kit; WSMV, Wheat streak mosaic virus.

He wheat CURL mite (Aceria tosichella Keifer) is a micro-
scopic $(70 \times 250 \mu \mathrm{m})$, soft-bodied, yellow-white, elongated arthropod of the order Acari and family Eriophyidae. Aceria tosichella was first described from tulip bulbs (Liliaceae) by Keifer in 1938 and later reported from onion (Allium cepa L.), garlic (Allium sativum L.), and several grass species (Poaceae), including common wheat (Triticum aestivum L. em. Thell.) (Slykhuis, 1955; Connin, 1956). A single female can produce more than three million eggs in $60 \mathrm{~d}$ under ideal conditions (Navia et al., 2013). Aceria tosichella may cause complete leaf trapping when infestation occurs

Published in Crop Sci. 59:1567-1575 (2019).

doi: 10.2135/cropsci2018.11.0695

(C) 2019 The Author(s). Re-use requires permission from the publisher. 
in young plants and cause mild rolling of leaf edges when infestations occur in older plants during spring (Staples and Allington, 1956).

More importantly, A. tosichella transmits Wheat streak mosaic virus (WSMV) (Slykhuis 1955), Wheat mosaic virus (WMoV), formerly known as High Plains virus (HPV) (Seifers et al., 1997; Skare et al., 2006; Hadi et al., 2011), Brome streak mosaic virus (BrSMV) (Götz and Maiss, 1995), and Triticum mosaic virus (TriMV) (Seifers et al., 2008, 2009). Virus symptoms include yellowing and rosette leaves and stunted plants, which usually can be observed on winter wheat as it undergoes stem elongation after winter dormancy. Outbreaks of WSMV are more severe if $A$. tosichella infestation occurs earlier during vegetative growth stages under warm temperatures (Wegulo et al., 2008). Therefore, $A$. tosichella is one of the most important wheat pests in the Great Plains of the United States and Canada, as well as in many other wheat-producing countries of Asia, Australia, Europe, and South America (Slykhuis, 1955; Keifer, 1969; Shevchenko et al., 1970; Martin et al., 1984; Harvey et al., 1990, 2002; Conner et al., 1991; Navia et al., 2013).

Given that no single effective measure exists for control of $A$. tosichella, genetic resistance in wheat has proven to be the most economical and environmentally safe strategy for reducing yield losses due to the combined effects of resistance to $A$. tosichella and associated viruses (Smith, 1999). To date, several genes conferring $A$. tosichella resistance have been reported. Thomas and Conner (1986) reported the first $A$. tosichella resistance gene (Cmc1) to be transferred from Aegilops tauschii (Coss.) Schmal. [syn. Ae. squarrosa L.; Triticum tauschii (Coss.) Schmal.] to wheat chromosome 6D (Thomas and Conner, 1986; Whelan and Thomas, 1989). Cmc2 resides on a translocation from Agropyron elongatum (Host) P. Beauv. in the same wheat 6DL chromosome (Martin et al., 1976; Whelan and Hart, 1988). Cmc3 is a gene on the 1AL.1RS translocation of rye (Secale cereale L.) in the wheat cultivar 'TAM 107' (PI 495594) and the breeding line KS96WGRC40 (PI 604225) (Malik et al., 2003b). KS96WGRC40 also carries an Ae. tauschii-derived A. tosichella resistance gene, Cmc4, on the short arm of chromosome 6D (Malik et al., 2003a). Although Cmc1, Cmc2, and Cmc4 are all on the chromosome 6D, they are independent loci (Malik et al., 2003a). In addition, several other unnamed genes have been reported: one from Haynaldia villosa (L.) Schur in a T6AL-6VS translocation line (Chen et al., 1996), one from wheat-Thinopyrum intermedium (Podp.) Barkworth \& DR Dewey partial amphiploids (Chen et al., 1998, 2003), and one in a wheat-Thinopyrum ponticum 6Ae/6DL Robertsonian translocation line (Thomas et al., 1998). More recently, a new gene, $C m c_{\text {TAM112 }}$, has been mapped on 6DS from a Texas cultivar 'TAM 112' (PI 643143) (Dhakal et al., 2018). However, its relationship with other genes on chromosome 6D is unknown.
In a previous study, Malik et al. (2003a) used a $\mathrm{F}_{2 \cdot 3}$ population derived from the cross KS96WGRC40 (Cmc4)/'Wichita' (Cltr 11952, A. tosichella susceptible) to locate Cmc4 on the distal end of 6DS at a 10.5 -cM interval between markers Xgdm141 and XksuG8. However, those two markers are still too far from $\mathrm{Cmc} 4$ and are not useful for marker-assisted selection (MAS). Another marker Xwms 904 was reported to be closely linked to Cmc4, but its primer sequence has been patented and is not publicly available for breeding selection (Malik et al., 2003a). In addition, they have not been validated in diverse genetic backgrounds. In the present study, we confirmed that the $A$. tosichella resistance gene in OK05312 is Cmc4, fine mapped Cmc4 using genotyping-by-sequencing (GBS)-based single nucleotide polymorphism (GBS-SNP) markers, and further converted a set of closely linked GBS-SNPs into high-throughput Kompetitive allele specific polymerase chain reaction (KASP) markers (Semagn et al., 2013) for efficient incorporation of Cmc4 into new wheat cultivars in breeding programs.

\section{MATERIALS AND METHODS Plant Materials}

A population of $186 \mathrm{~F}_{5: 6}$ recombinant inbred lines (RILs) was developed from the cross of 'Jerry'/OK05312 using single-seed descent. Jerry, developed by North Dakota State University, is a hard winter hexaploid wheat derived from the cross 'Roughrider'/ND7571//'Arapahoe' and is susceptible to $A$. tosichella (Peel et al., 2004). OK05312 is an advanced hexaploid hard winter wheat breeding line with the pedigree TX93V5919/ KS96WGRC40//OK94P549/KS96WGRC34 (PI 604219) and was developed by Oklahoma State University in cooperation with the USDA-ARS (Cox et al., 1999; Carver et al., 2016). It has better agronomic traits than KS96WGRC40 and was thus released as an agronomically improved source of $\mathrm{Cmc} 4$ for $A$. tosichella resistance. The wheat cultivar 'Jagger' (PI 593688) was used as an $A$. tosichella-susceptible check and TAM 107, which contains $\mathrm{Cmc} 3$, as an $A$. tosichella Type 1 resistant check (Harvey and Martin, 1992; Harvey et al., 1997; Sears et al., 1997, Dhakal et al., 2017). Validation with KASP markers was conducted using a natural US winter wheat population included elite breeding lines from regional performance nurseries and newly released cultivars. OK05312 was included in the population as the positive control.

\section{Wheat Curl Mite Maintenance and Infestation}

Greenhouse experiments were started on 10 Mar. 2014 (Exp. I) and 25 Apr. 2014 (Exp. II) at Kansas State University, Manhattan, KS. Biotype 1 of $A$. tosichella was used for infestation because it is predominant in Kansas and used in several previous studies (Malik et al., 2003a, 2003b). The Biotype 1 colony originated from Tripp County, South Dakota, and was collected and supplied courtesy of Dr. Ada Szczepaniec, South Dakota State University, maintained on the wheat curl mite-susceptible wheat cultivar Jagger, and periodically verified by polymerase chain reaction (PCR) using the ITS1 marker (Malik, 2001). Wheat curl mite eggs are periodically 
transferred to healthy plants to provide viruliferous wheat curl mites. For mite infestation, plants of the RIL population were grown in 72-cell germination trays containing Pro-Mix 'Bx' potting mix (Premier ProMix). Five plants per genotype were grown in each experiment without replication. A total of five plants per parent and control were planted in the first experiment, and 10 plants per parent and control were planted in the second experiment. To phenotype plant reaction to $A$. tosichella, the leaf whorls of five test plants of each RIL and control were infested with 10 viruliferous $A$. tosichella adult mites at the two-leaf stage, and plants were covered by a mite-proof cage made of 36- $\mu \mathrm{m}$ mesh and left undisturbed for $21 \mathrm{~d}$ at $24 / 20^{\circ} \mathrm{C}$ day/night, and a photoperiod of 14/10 h light/dark for development of mite and virus symptoms. Plants were scored individually for resistance or susceptibility at $21 \mathrm{~d}$ after mite infestation based on the degree of symptom expression in the susceptible control plants. Plants with normal leaves were rated as resistant, and plants with curled or trapped leaves were scored as susceptible. In addition, leaves of the five seedlings per genotype from the 10 March experiment were pooled and subjected to enzyme-linked immunosorbent assays (ELISAs) for WSMV, using a protocol described previously (Chuang et al., 2017).

\section{DNA Extraction}

Leaf tissue from each genotype was sampled at the two-leaf stage into 1.1-mL-deep well plates with each well containing a 3.2-mm stainless steel bead. The plates with tissue were freeze dried for $48 \mathrm{~h}$ in a freeze dryer (Thermo Fisher) and shaken in a mixer mill (Retsch) at 25 cycles s$^{-1}$ for $5 \mathrm{~min}$. Genomic DNA was extracted using a modified cetyltrimethyl ammonium bromide method (Bai et al., 1999).

\section{Genotyping-by-Sequencing Library Construction and SNP Identification}

A GBS library was constructed for 186 RILs and two parents in two 96-well plates following Poland et al. (2012). Parental samples had three replications each. In brief, DNA samples were digested with the PstI-HF (high fidelity) and MspI restriction enzymes (New England BioLabs), and ligated to barcoded adapters and a Y common adaptor using T4 DNA ligase (New England BioLabs). All ligation products in the two 96-well plates were pooled and cleaned up using the QIAquick PCR Purification Kit (Qiagen). Primers complementary to both adapters were used for PCR. The PCR products were then cleaned up again using the QIAquick PCR Purification Kit and size selected for a range of 250 to $300 \mathrm{bp}$ in an E-gel system (Life Technologies). The DNA concentration was estimated in the Qubit 2.0 fluorometer using a Qubit dsDNA HS Assay Kit (Life Technologies). The size-selected library was sequenced for three runs on an Ion Proton system (Life Technologies).

Single nucleotide polymorphisms were called using a reference-free Universal Network-Enabled Analysis Kit (UNEAK) pipeline implemented in the TASSEL (Bradbury et al., 2007) because the wheat reference genome was not available in 2014 when the GBS was analyzed, and also because the UNEAK pipeline directly provided GBS sequences that carry target SNPs from the parents and are therefore more accurate for KASP marker design than the sequences from the Chinese Spring reference in the reference-based pipeline. Raw sequence reads were parsed and assigned to samples according to barcodes and trimmed to $64 \mathrm{bp}$ in length. To identify SNPs in the population, all pairs of tags were evaluated first for 1- or 2-bp differences. Biallelic SNPs were determined by querying the filtered tags for pairs of sequences (Poland et al., 2012) if they differed in only one or two SNPs. Only the SNPs that were present between parents and in at least $80 \%$ genotypes of the population were used for further map construction. Because RILs were used for library construction, SNPs with heterozygotes $>10 \%$ of the total number of RILs were discarded to reduce the false positive results.

\section{Analysis of SSR Markers}

Three simple sequence repeat (SSR) markers, Xgdm141 and Xwms 904 closely linked to Cmc4 (Malik et al., 2003a) and Xscm 9 on rye chromosome arm 1RS, were analyzed to verify presence of Cmc4 and absence of $\mathrm{Cmc}_{3}$ in the RIL population. The PCR amplifications were performed in a Tetrad Peltier DNA engine (Bio-Rad Laboratories) following Malik et al. (2003a). The PCR products were separated on an ABI PRISM 3730 DNA analyzer (Applied Biosystems). The data were scored using GeneMarker (SoftGenetics, 2014).

\section{Linkage Map Construction and QTL Mapping}

A linkage map was initially constructed using SNPs generated from GBS using the 'Regression' function in JoinMap version 4.0 (Van Ooijen, 2006). Recombination fractions were converted to centimorgans using the Kosambi function (Kosambi, 1944). The linkage groups were assigned to chromosomes based on the previously published Chinese Spring reference genome RefSeq v1.0 by The International Wheat Genome Sequencing Consortium (IWGSC, 2018). Phenotypic data from the two experiments were separately analyzed for quantitative trait locus (QTL) detection, and mean infestation rates from the two experiments were also calculated for QTL detection. Quantitative trait locus mapping was conducted using composite interval mapping modules in QTL Cartographer version 2.5 (Wang et al., 2012). Significant LOD threshold of three was selected for all datasets based on 1000 permutations (Doerge and Churchill, 1996) with a Type I error rate of $<0.05$.

\section{Conversion of GBS-SNPs into KASP Markers}

Initially, a map of GBS-SNPs was used to identify QTL location. To fill in missing GBS data in detected QTL region, GBS-SNPs mapped around the QTL region were selected for conversion of KASP markers. The KASP primers were designed using the Polymarker pipeline (http://polymarker. tgac.ac.uk/) that designs homoeologue-specific KASP assays for the polyploid wheat genome. The KASP assay was performed following manufacturer's instruction (http://www.lgcgroup. com/LGCGroup/media/PDFs/Products/Genotyping/KASPgenotyping-chemistry-User-guide.pdf). The newly designed KASP primers were then tested for parental polymorphisms, and the polymorphic SNPs were genotyped in the mapping population. The new linkage map was reconstructed for final QTL analysis after the newly developed polymorphic KASPSNPs replaced their corresponding GBS-SNPs.

The KASP assay was performed in a $6-\mu \mathrm{L}$ PCR mix that consisted of $2.9 \mu \mathrm{L}$ of reaction mix (LGC Genomics), $0.1 \mu \mathrm{L}$ of 
primer assay mix, and $3 \mu \mathrm{L}$ of DNA at a concentration of $15 \mathrm{ng}$ $\mu \mathrm{L}^{-1}$. Polymerase chain reaction was assayed following manufacturer's instruction (LGC Genomics) using an ABI 7900HT real-time PCR system (Life Technology).

\section{RESULTS}

\section{Wheat Curl Mite Resistance in the Jerry/OK05312 RIL Population}

All parents and controls were infested with $A$. tosichella US Biotype 1. However, the percentage of infested plants differed between the susceptible genotypes (the susceptible control Jagger and the susceptible parent Jerry) and the resistant genotypes (the resistant parent OK05312 and the resistant control TAM 107). Jagger showed the highest mean infestation rate with $87 \%$ susceptible plants, Jerry the second with 67\% susceptible plants, and OK05312 and TAM 107 the lowest with only 7\% infested plants over the two experiments. The difference between the resistant and susceptible parents was significant $(p<0.01)$. The frequency distribution of percentage of infested plants in the RIL population was continuous with $\sim 50 \%$ of the RILs being the resistant genotypes that had at least $90 \%$ resistant plants per RIL (Fig. 1), suggesting that one major gene may confer A. tosichella resistance in OK05312. In addition, transgressive segregation was also observed for resistance.

\section{Construction of a Linkage Map with GBS-SNPs for QTL Mapping}

Genotyping-by-sequencing generated a total of 13,730 SNPs. Among them, 2048 SNPs had <20\% missing data, and 1526 of them were mapped into
46 linkage groups that were anchored to 21 chromosomes. The linkage map has a total length of 2369 cM with an average marker density of $1.55 \mathrm{cM}$ per marker and 5 to 130 markers per linkage group.

One major QTL associated with $A$. tosichella resistance and low value of ELISA was identified in each experiment and for mean from the two experiments. The QTL was located on the short arm of chromosome $6 \mathrm{D}$, with OK05312 providing the allele for $A$. tosichella resistance (Fig. 2).

\section{Conversion of GBS-SNPs to Enabling KASP Markers}

To verify the SNP data generated by GBS and fill in missing data for the markers in the QTL region, 20 sequences carrying GBS-SNPs mapped in the distal end of 6DS, where the $A$. tosichella resistance QTL was located, were used to design KASP assays to screen two parents for polymorphisms. Twelve KASP-SNPs were polymorphic between the parents (Table 1) and showed similar segregation patterns to their corresponding GBS-SNPs in the RIL population with zero to three mismatches between KASP and GBS data per marker in 186 lines analyzed. Among those KASP-SNP markers, four markers had a mismatch in one RIL; four had two mismatches in two different RILs; one (370SNP2013) had three mismatches in three different RILs; and three had perfect matches. The 12 KASP-SNPs were remapped to (or close to) the original positions in the map because of a low average mismatch rate $(0.68 \%)$ between GBS-SNPs and KASPSNPs. The 15 mismatched SNP calls between KASP and

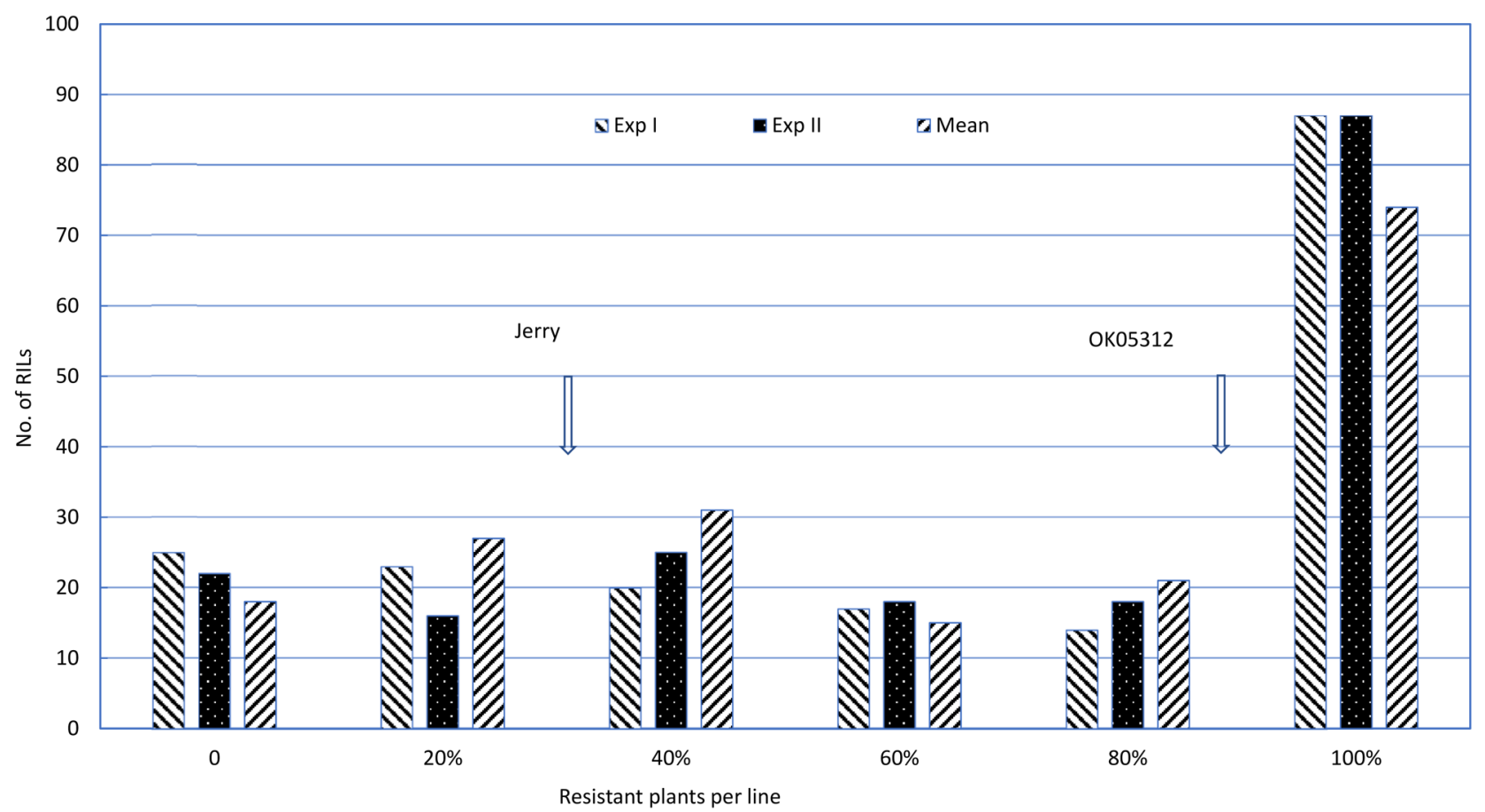

Fig. 1. Frequency distribution for the percentage of wheat curl mite resistant lines in the recombinant inbred line (RIL) population of Jerry/ OK05312 evaluated in two experiments. Mean refers to average from the two experiments (Exp. I and Exp. II). 


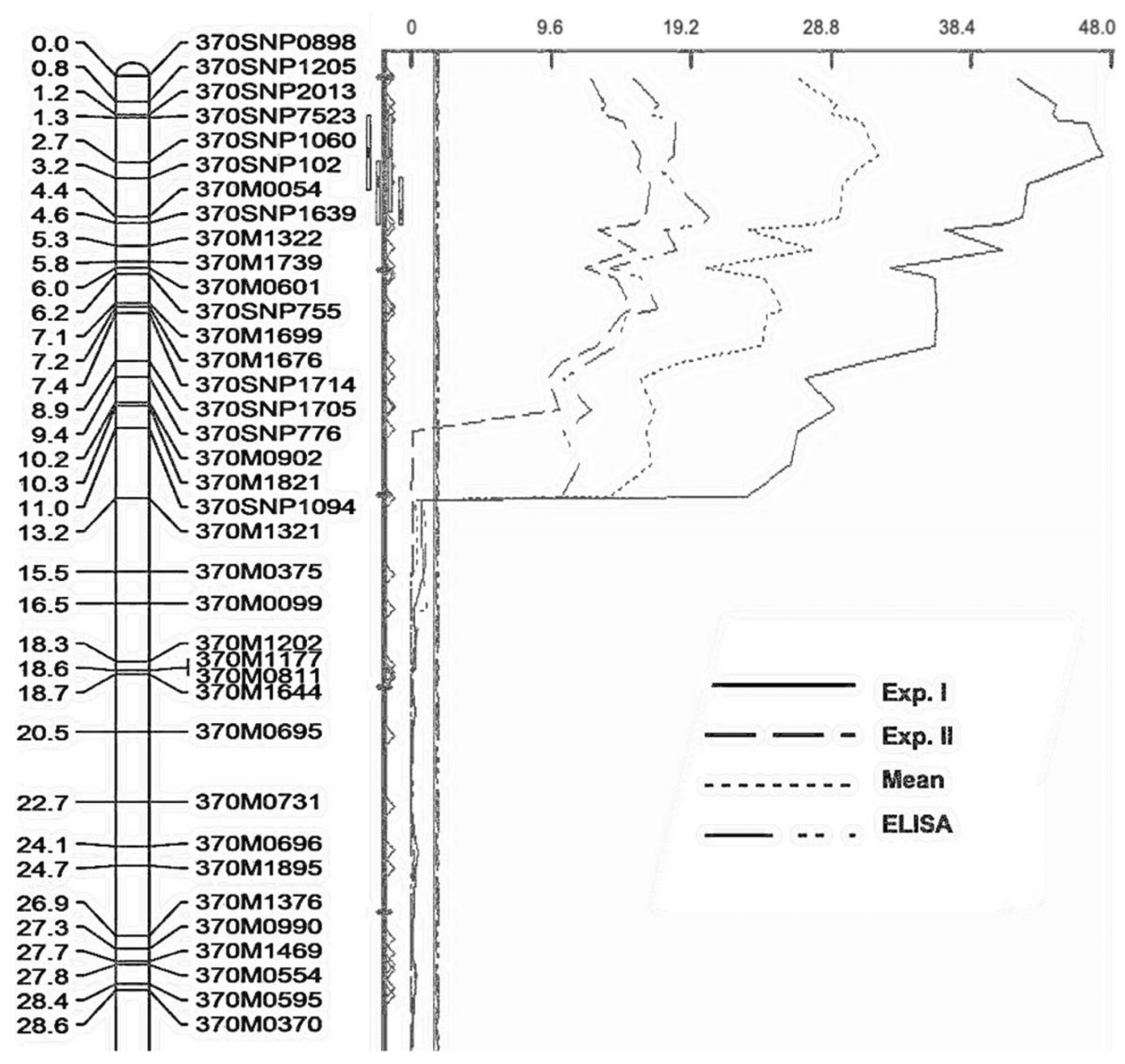

Fig. 2. A partial linkage map for wheat curl mite resistance quantitative trait loci (QTLS) identified on the distal end of chromosome arm 6DS. Genetic distances in centimorgans are shown on the left side linkage map and marker names are shown on the right. The QTL data from Exp. I, Exp. II, mean, and enzyme-linked immunosorbent assay (ELISA) are plotted by red, black, blue, and green lines, respectively. Bars for the QTL positions from left to right are calculated using data from Exp. I, Exp. II, mean, and ELISA, respectively. The numbers on the top of the QTL plot are logarithm of the odds (LOD) values.

Table 1. List of primers for polymorphic Kompetitive allele specific polymerase chain reaction (KASP)-single nucleotide polymorphism (SNP) markers developed in this study and their estimated physical distances in the Chinese Spring wheat reference genome (IWGSC, 2018) and the A. tauschii reference genome (Luo et al., 2018).

SNP markers Forward primers (Jerry/OK05312)†

Physical distance in Physical distance in $A$.

\begin{tabular}{|c|c|c|c|c|}
\hline SNP markers & Forward primers (Jerry/OK05312)† & Reverse primers & Chinese Spring & tauschii \\
\hline & & & - & $\longrightarrow$ \\
\hline 370SNP0898 & TCTGCTACTCAAATGCATGg/t & CGGCTGTGTATGGTGTAAC & $1,602,580-1,602,643$ & 1,418,676-1,418,739 \\
\hline $370 S N P 1205$ & CCСTTCTGCAGCTTGTAc/t & AGCTTGCTCCCCAAGCTC & $2,325,387-2,325,449$ & $2,000,396-2,000,523$ \\
\hline $370 S N P 6314$ & CGCCCTTCTGCAGCTTGTAc/t & AGCTTGCTCCCCAAGCTC & $2,325,379-2,325,436$ & $2,000,466-2,000,523$ \\
\hline 370SNP2013 & GGTTATGTGCTGCAGTTCt/g & ACGGGCGTCACTAACAAC & $2,523,758-2,523,821$ & No match sequence \\
\hline $370 S N P 7523$ & TTGCCGATCCAAGCCACa/C & GCTGCTGAGAATTTTGTTTT & $2,240,736-2,240,799$ & $2,101,778-2,101,841$ \\
\hline $370 S N P 1060$ & CAGGCTGCAGCTCATTTt/c & CTGTGGAGCTCGGTTTTAG & $2,914,472-2,914,535$ & 2,818,042-2,818,105 \\
\hline 370SNP102 & GACGACCACCAGAGAGAAGg/a & GCCTGCCCGTCTTGTT & $3,041,197-3,041,260$ & $2,874,075-2,874,138$ \\
\hline $370 S N P 1639$ & GTGCACTGTCACGGAGCg/a & GTTTGCGGCAATACTCATCG & $3,912,903-3,912,966$ & No match sequence \\
\hline $370 S N P 755$ & TGCAGCCACAACAGGACAc/t & CGCATGTGAAAGACAGTGATG & $5,046,882-5,046,945$ & $4,801,965-4,802,027$ \\
\hline $370 S N P 1714$ & CTGCTCATGCCTGCATCa/g & GAGTGCATATAGACTAGCTATGGAGTTG & $5,255,879-5,255,942$ & $4,818,680-4,818,744$ \\
\hline 370SNP1705 & CTTCATGAGCGGAGCCa/c & GCTGATGCGCACCAACTAC & $6,106,322-6,106,385$ & $5,361,409-5,361,472$ \\
\hline $370 S N P 776$ & GGCAATGTGAAGGTCAGCTTg/a & GCCATCGTTCCATCAAGTAAA & $6,343,670-6,343,728$ & $5,687,936-5,687,994$ \\
\hline 370SNP1094 & GTGCAATCAAGCCAGGGt/c & CAGCTCTATCTGCACCCACA & $7,172,887-7,172,950$ & $6,446,854-6,446,917$ \\
\hline
\end{tabular}

† Last two letters separated by a backslash indicate the polymorphic nucleotides in Jerry (the letter before the slash) and OK05312 (after the back slash). 
GBS were present in six RILs, including five in RIL179, four in RIL141, three in RIL147 and one each in RILs 78, 155, and 178.

After the map was updated with the KASP markers, the major QTL for $A$. tosichella resistance was delimited to a 3.3-cM interval between KASP markers 370SNP7523 and 370 SNP1639 and explained 71.31 and $30.58 \%$ of the phenotypic variation in the two experiments, respectively, and $49.94 \%$ of the phenotypic variation for the mean of the two experiments (Table 2, Fig. 2). A QTL from ELISA data was also located in this region and explained $35.72 \%$ of the phenotypic variation. Therefore, the 3.3-cM chromosome region between markers 370SNP7523 and 370 SNP1639 is the critical region for curl mite resistance in OK05312.

To validate the usefulness of the two KASP markers (370SNP7523 and 370SNP1639) in MAS, they were analyzed for allele distribution in a wheat population. This population include both hard and soft US winter wheat cultivars and breeding lines. Both markers amplified the positive alleles in accessions NW03666 and OK05312, not in the other accessions, except that 370SNP1639 has the positive allele in HV9W96-1271R-1 (Supplemental Table S1). Those results suggest a high level of polymorphism of the two markers between OK05312 and other US winter wheat cultivars and elite breeding lines.

\section{Annotated Putative Genes in the Cmc4 Flanking Region}

A Basic Local Alignment Search Tool (BLAST) search using the sequences of the two flanking markers for the mite resistance QTL located a physical distance of 1672 $\mathrm{kb}$ between the flanking markers 370SNP7523 (2241 kb) and 370 SNP1639 (3913 kb, Table 1). A total of 55 putative genes were predicted in this region using Chinese Spring RefSeq v1.0 (IWGSC, 2018). Six were annotated as disease resistance genes, including an nucleotide binding site (NBS)-leucine-rich repeat (LRR)-like resistance protein, three LRR receptor-like protein kinase family proteins, a protein-enhanced disease resistance 2-like protein, and a Toll interleukin-1 receptor (TIR)-NBSLRR class disease resistance protein. Using the Aegilops tauschii reference (Luo et al., 2018), at least 34 genes were annotated with a high confidence in the syntenic region (Supplemental Table S2), and two of them are putative disease resistance genes (a protein-enhanced disease resistance 2-like protein and a TIR-NBS-LRR class disease resistance protein). Those two putative resistance genes were also found in the syntenic region of the hexaploid wheat Chinese Spring reference (IWGSC, 2018).

\section{Analysis of DNA Markers Linked to $\mathrm{Cmc} 4$ in the RIL Population}

Blast search of these SNP sequences presented in Table 2 against the Chinese Spring wheat reference sequence indicated that the newly identified QTL is on the distal end of short arm of chromosome 6D. To verify if the QTL was Cmc4, two previously reported DNA markers were genotyped in the RIL population: Xwms904 was the closest marker to Cmc4, and Xgdm141 was one of the flanking markers (Malik et al., 2003a). Xwms904 amplified a target fragment of $115 \mathrm{bp}$ in Jerry and did not amplify any PCR product in OK05312. Xgdm141 amplified a target band of $147 \mathrm{bp}$ in OK05312 and $127 \mathrm{bp}$ in the Jerry. When these markers were analyzed together with GBS-SNP data, Xwms904 was 1.3 cM from 370SNP1639, one of the flanking markers for the QTL mapped in Jerry $\times$ OK05312 population, confirming that the QTL in OK05312 is Cmc4. Xgdm141 was mapped at $42.4 \mathrm{cM}$ to 370SNP1639; therefore, the newly developed flanking markers for Cmc4, 370SNP7523 and 370SNP1639, are closer to Cmc4 than Xwms904 and Xgdm141.

\section{DISCUSSION}

To date, only four named (Cmc1, Cmc2, Cmc3, and Cmc4) and two unnamed $A$. tosichella resistance genes have been reported and transferred into wheat from wheat relative species (Thomas and Whelan, 1991; Chen et al., 1996, 1998, 2003; Malik et al., 2003a; Dhakal et al., 2018), and KS96WGRC40 carries two of them, Cmc4 and Cmc3

Table 2. Chromosome peak positions, marker intervals, and effects of the quantitative trait locus (QTL), detected for wheat curl mite resistance in a Jerry/OK05312 recombinant inbred line population

\begin{tabular}{|c|c|c|c|c|c|c|}
\hline Experiment & Position & Marker interval & Physical interval & LOD† & PVE $\ddagger$ & ADD§ \\
\hline & $\mathrm{cM}$ & & $\mathrm{Mb}$ & & + & 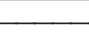 \\
\hline Exp. I & 2.3 & 370SNP7523-370SNP102 & $2.24-3.04$ & 47.51 & 71.31 & 31.84 \\
\hline Exp. II & 3.2 & 370SNP1060-370M0054ף & $2.91-3.62$ & 16.42 & 30.58 & 23.59 \\
\hline Mean & 2.3 & 370SNP7523-370M0054 & $2.24-3.62$ & 35.03 & 49.94 & 27.97 \\
\hline ELISA\# & 4.2 & 370SNP102-370SNP1639 & $3.04-3.91$ & 20.44 & 35.72 & 36.44 \\
\hline
\end{tabular}

† LOD, logarithm of odds value

‡ PVE, phenotypic variation explained.

$\S A D D$, additive effect, where a positive value implies that the OK05312 allele for resistance to wheat curl mite.

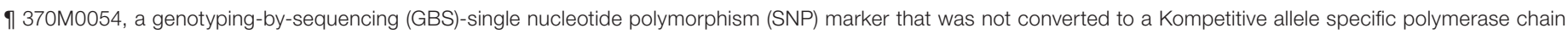
reaction (KASP)-SNP.

\# ELISA, enzyme-linked immunosorbent assay. 
(Malik et al., 2003a, 2003b). Cmc3 is on a 1AL.1RS translocation of rye chromosome arm $1 \mathrm{R}$ to chromosome arm 1AL of 'Amigo' wheat (Dhakal et al., 2018). KS96WGRC40 is the only parent that carries curl mite resistance genes (Carver et al., 2016); therefore, the resistance gene(s) in OK05312 is (are) from KS96WGRC40.

Previous studies indicated that OK05312 was resistant to both $A$. tosichella biotypes in the US Great Plains, whereas TAM 107 carrying Cmc3 showed resistance to only Biotype 1 (a less virulent biotype), not Biotype 2 (Carver et al., 2016; Dhakal et al., 2017). Therefore, we selected $A$. tosichella Biotype 1 for phenotyping of the mapping population to determine if both $\mathrm{Cmc3}$ and $\mathrm{Cmc} 4$ genes are present in OK05312. Using the newly developed high-density SNP map, only one QTL for $A$. tosichella resistance was identified on chromosome arm 6DS, and a QTL on chromosome arm 1AS was not found. Analysis of 1RS specific marker Xscm9 also confirmed absence of 1R chromosome arm in OK05312, excluding Cmc3 from OK05312. Therefore, Cmc4 is the only gene for A. tosichella resistance in OK05312, which was also confirmed by mapping Xwms904, the closest marker to Cmc4 (Malik et al., 2003a), in the QTL region of OK05312.

To our knowledge, only one study reported gene mapping of Cmc4 in wheat (Malik et al., 2003a). In that study, only eight markers were mapped in the linkage group harboring $\mathrm{Cmc4}$, and those markers covered $\sim 90 \mathrm{cM}$ of chromosome $6 \mathrm{D}$ at a low marker density of $11 \mathrm{cM}$ per marker. Two markers, Xgdm141 and XksuG8, were reported to flank Cmc4 in a $\sim 10$-cM interval (Malik et al., 2003a). More recently, Dhakal et al. (2018) reported a gene, $C m c_{\text {TAM112 }}$, on the chromosome arm 6DS of TAM 112 (PI 643143) that effectively reduced symptom severity when plants were infested with either biotypes of $A$. tosichella from Texas, but its relationship with Cmc4 was not determined in that study. However, the physical location of $C m c_{\text {TAM112 }}(1.4-2.2 \mathrm{Mb})$ is tightly close to or overlapped with that of $\mathrm{Cmc}_{4}(2.2-3.9 \mathrm{Mb})$ as detected in this study, suggesting that these two genes are likely the same locus, but further research is needed to confirm this.

The current study generated thousands of SNP markers for the RIL population using GBS and constructed a highdensity map with 1526 SNPs for QTL scan. Among these mapped SNPs, 77 were mapped in a linkage group that harbors Cmc4 and cover a total length of $65 \mathrm{cM}$ on 6DS. In this region, we identified a small interval of $\sim 3.3 \mathrm{cM}$ for Cmc4. Xwms904, the closest marker to Cmc4 (Malik et al., 2003a), was located at $1.2 \mathrm{cM}$ proximal to 370SNP1639, one of the two flanking markers to Cmc4 identified in current study; Xgdm141, one of the previously reported flanking marker, was located at $\sim 41.2 \mathrm{cM}$ proximal to $370 S N P 1739$, indicating that the gene region defined in this study is much smaller than that reported previously (Malik et al., 2003a).
Four KASP-SNPs were identified within the Cmc4 interval. Identification of these closely linked SNPs to Cmc4 provides useful markers for further fine mapping or cloning the gene. Previous deletion mapping of the linked markers to the gene showed that the Ae. tauschii-derived fragment carrying Cmc4 is in the distal end of chromosome arm 6DS within the bin interval 0.99 to 1.00 (Malik et al., 2003a). Physical mapping of Cmc4 using Chinese Spring reference delimited the gene to a 1.7-Mb interval between 2.2 and $3.9 \mathrm{Mb}$, suggesting that the fragment carrying Cmc4 is short, is on the distal end of 6DS, and can therefore be easily transferred from OK05312 into new wheat cultivars. OK05312 is a commercial-ready genetic stock, shows resistance to both curl mite biotypes in the US Great Plains, and could be directly released as a variety. However, commercially wide-scale deployment of $\mathrm{Cmc} 4$ as a unilateral defense to WSMV may not be a good example of responsible gene stewardship (Carver et al., 2016); thus, pyramiding Cmc4 with other resistance genes in new cultivars may provide durable resistance to WSMV.

Previously available markers linked to Cmc4 were mainly SSR and restriction fragment length polymorphism (RFLP) markers (Malik et al., 2003a). An RFLP marker is not suitable for practical breeding application due to its low throughput and technical complexity. For two previously reported SSR markers, Xgdm141, one of the flanking marker of Cmc4, is too far from Cmc4 $(>42 \mathrm{cM})$ in the current study, whereas other SSR marker, Xwms904 (Malik et al., 2003a), has been patented and is not publicly available. To effectively use Cmc4 in breeding, tightly linked and high-throughput markers are needed. In this study, many GBS-SNPs were mapped in the gene region, which significantly shortened the region and more precisely pinpointed the gene interval to $1.7 \mathrm{Mb}$. However, GBS-SNPs are still not suitable for screening a large number of breeding samples due to high technical demand and relatively high cost per sample. The KASP marker has the advantages of easy assaying and low cost per sample and is also suitable for high-throughput screening. To develop enabling markers for breeding applications, we successfully converted 12 SNPs that segregated in the RIL population. Among them, 370 SNP7523 and 370 SNP1639 flank Cmc4 and were analyzed in a natural population of US winter wheat cultivars and breeding lines. In this population, Cmc4 is not expected according to their known pedigrees (Supplemental Table S1). The two markers identified only one line as positive except the OK05312 control; therefore, those markers are nearly diagnostic and should be very useful for MAS to select for Cmc4 in breeding programs.

Candidate gene analysis using both Chinese Spring and A. touschii reference sequences identified 55 and 34 annotated high confidence genes in the putative $\mathrm{Cmc} 4$ region. Among them, two putative resistance genes, a protein-enhanced 
disease resistance 2-like protein, and a TIR-NBS-LRR class disease resistance protein were identified in both genomes. They can be considered as important candidates for further map-based cloning of Cmc4.

\section{Supplemental Material Available}

Supplemental material is available online for this article.

\section{Conflict of Interest}

On behalf of all authors, the corresponding author states that there is no conflict of interest.

\section{Acknowledgments}

This is Contribution no. 18-351-J from the Kansas Agricultural Experiment Station. This project is partly funded by the National Research Initiative Competitive Grants 2017-6700725939 and 2017-67007-25929 from the USDA National Institute of Food and Agriculture, and mention of trade names or commercial products in this publication is solely for the purpose of providing specific information and does not imply recommendation or endorsement by the US Department of Agriculture. The USDA is an equal opportunity provider and employer.

\section{References}

Bai, G., F. Kolb, G.E. Shaner, and L. Domier. 1999. Amplified fragment length polymorphism markers linked to a major quantitative trait locus controlling scab resistance in wheat. Phytopathology 89:343-348. doi:10.1094/ PHYTO.1999.89.4.343

Bradbury, P.J., Z. Zhang, D.E. Kroon, T.M. Casstevens, Y. Ramdoss, and E.S. Buckler. 2007. TASSEL: Software for association mapping of complex traits in diverse samples. Bioinformatics 23:2633-2635. doi:10.1093/bioinformatics/btm308

Carver, B.F., C.M. Smith, W.-P. Chuang, R.M. Hunger, J.T. Edwards, L. Yan, et al. 2016. Registration of OK05312, a high yielding hard winter wheat donor of Cmc4 for wheat curl mite resistance. J. Plant Reg. 10:75-79. doi:10.3198/ jpr2015.04.0026 crg

Chen, Q., R.L. Conner, F. Ahmad, A. Laroche, G. Fedak, and J.B. Thomas. 1998. Molecular characterization of the genome composition of partial amphiploids derived from Triticum aestivum $\times$ Thinopyrum ponticum and T. aestivum $\times$ Th. intermedium as sources of resistance to Wheat streak mosaic virus and its vector, Aceria tosichella. Theor. Appl. Genet. 97:1-8. doi:10.1007/s001220050860

Chen, Q., R.L. Conner, and A. Laroche. 1996. Molecular characterization of Haynaldia villosa chromatin in wheat lines carrying resistance to wheat curl mite colonization. Theor. Appl. Genet. 93:679-684. doi:10.1007/BF00224062

Chen, Q., R.L. Conner, H.J. Li, S.C. Sun, F. Ahmad, A. Laroche, and R.J. Graf. 2003. Molecular cytogenetic discrimination and reaction to Wheat streak mosaic virus and the wheat curl mite in Zhong series of wheat-Thinopyrum intermedium partial amphiploid. Genome 46:135-145. doi:10.1139/g02-109

Chuang, W.P., L.M. Aguirre-Rojas, L.K. Khalaf, G. Zhang, A.K. Fritz, A.E. Whitfield, and C.M. Smith. 2017. Wheat genotypes with combined resistance to wheat curl mite, Wheat streak mosaic virus, Wheat mosaic virus, and Triticum mosaic virus. J. Econ. Entomol. 110:711-718. doi:10.1093/jee/tow255
Conner, R.L., J.B. Thomas, and E.D.P. Whelan. 1991. Comparison of mite resistance for control of Wheat streak mosaic. Crop Sci. 31:315-318. doi:10.2135/cropsci1991.0011183X00310002 $0018 \mathrm{x}$

Connin, R.V. 1956. The host range of the wheat curl mite, vector of wheat streak-mosaic. J. Econ. Entomol. 49:1-4. doi:10.1093/jee/49.1.1

Cox, T.S., W.W. Bokus, B.S. Gill, R.G. Sears, T.L. Harvey, and S. Leath. 1999. Registration of KS96WGRC40 hard red winter wheat germplasm resistant to wheat curl mite, Stagnospora leaf blotch, and Septoria leaf blotch. Crop Sci. 39:597. doi:10.2135/ cropsci1999.0011183X003900020070x

Dhakal, S., C.T. Tan, V. Anderson, H. Yu, M.P. Fuentealba, J.C. Rudd, et al. 2018. Mapping and KASP marker development for wheat curl mite resistance in TAM 112 wheat using linkage and association analysis. Mol. Breed. 38:119. doi:10.1007/ s11032-018-0879-x

Dhakal, S., C.T. Tan, L. Paezold, M.P. Fuentealba, J.C. Rudd, Q. Xue, et al. 2017. Wheat curl mite resistance in hard winter wheat in the US Great Plains. Crop Sci. 57:53-61. doi:10.2135/cropsci2016.02.0121

Doerge, R.W., and G.A. Churchill. 1996. Permutation tests for multiple loci affecting a quantitative character. Genetics 142:285-294.

Götz, R., and E. Maiss. 1995. The complete nucleotide-sequence and genomic organization of the mite-transmitted Brome streak mosaic rymovirus in comparison with those of potyviruses. J. Gen. Virol. 76:2035-2042. doi:10.1099/0022-1317-76-8-2035

Hadi, B.A.R., M.A.C. Langham, L. Osborne, and K.J. Tilmon. 2011. Wheat streak mosaic virus on wheat: Biology and management. J. Integr. Pest Manage. 2:J1-J5. doi:10.1603/IPM10017

Harvey, T.L., T.J. Martin, and D.L. Seifers. 1990. Wheat curl mite and wheat streak mosaic in moderate trichome density wheat cultivars. Crop Sci. 30:534-536. doi:10.2135/cropsci1990.001 1183X003000030011x

Harvey, T.L., T.J. Martin, and D.L. Seifers. 2002. Wheat yield reduction due to wheat curl mite (Acari: Eriophyidae) infestations. J. Agric. Urban Entomol. 19:9-13.

Harvey, T.L., T.J. Martin, D.L. Seifers, and P.E. Sloderbeck. 1997. Change in virulence of wheat curl mite detected on TAM 107 wheat. Crop Sci. 37:624-625. doi:10.2135/cropsci1997.00111 83X003700020052x

Harvey, T.L., and T.J. Martin. 1992. Resistance to the wheat curl mite (Acari:Eriophyidae) in common wheat. Cereal Res. Commun. 20:63-66.

International Wheat Genome Sequencing Consortium (IWGSC). 2018. Shifting the limits in wheat research and breeding using a fully annotated reference genome. Science 361:eaar 7191. doi:10.1126/science.aar7191

Keifer, H.H. 1969. Eriophyid studies C-3. USDA-ARS Spec. Publ. U. S. Gov. Print. Office, Washington, DC.

Kosambi, D.D. 1944. The estimation of map distances from recombination values. Ann. Eugen. 12:172-175. doi:10.1111/j.1469-1809.1943.tb02321.x

Luo, M.-C., Y.Q. Gu, D. Puiu, H. Wang, S.O. Twardziok, K.R. Deal, et al. 2018. Genome sequence of the progenitor of the wheat D genome Aegilops tauschii. Nature 511:498-502. doi:10.1038/nature24486

Malik, R. 2001. Molecular genetic characterization of wheat curl mite, Aceria tosichella Keifer (Acari: Eriophyidae), and wheat genes conferring wheat curl mite resistance. Ph.D. diss., Kansas State Univ., Manhattan. 
Malik, R., G.L. Brown-Guedira, C.M. Smith, T.L. Harvey, and B.S. Gill. 2003a. Genetic mapping of wheat curl mite resistance genes $\mathrm{Cmc3}$ and $\mathrm{Cmc4}$ in common wheat. Crop Sci. 43:644-650. doi:10.2135/cropsci2003.0644

Malik, R., C.M. Smith, G.L. Brown-Guedira, T.L. Harvey, and B.S. Gill. 2003b. Assessment of Aegilops tauschii for resistance to biotypes of wheat curl mite (Acari: Eriophyidae). J. Econ. Entomol. 96:1329-1333. doi:10.1093/jee/96.4.1329

Martin, T.J., T.L. Harvey, C.G. Bender, and D.L. Seifers. 1984. Control of Wheat streak mosaic virus with vector resistance in wheat. Phytopathology 74:963-964. doi:10.1094/Phyto-74963

Martin, T.J., T.L. Harvey, and R.W. Livers. 1976. Resistance to Wheat streak mosaic virus and its vector, Aceria tulipae. Phytopathology 66:346-349. doi:10.1094/Phyto-66-346

Navia, D., R.S. de Mendonc, A. Skoracka, W. Szydło, D. Knihinicki, G.L. Hein, et al. 2013. Wheat curl mite, Aceria tosichella, and transmitted viruses: An expanding pest complex affecting cereal crops. Exp. Appl. Acarol. 59:95-143. doi:10.1007/ s10493-012-9633-y

Peel, M.D., J.A. Anderson, J.B. Rasmussen, J.D. Miller, T.C. Olsen, and G.W. Johnson. 2004. Registration of Jerry wheat. Crop Sci. 44:1026-1027. doi:10.2135/cropsci2004.1026

Poland, J.A., P.J. Brown, M.E. Sorrells, and J.L. Jannink. 2012. Development of high-density genetic maps for barley and wheat using a novel two-enzyme genotyping-by-sequencing approach. PLoS One 7:e32253. doi:10.1371/journal. pone.0032253

Sears, R.G., J.M. Moffatt, T.J. Martin, T.S. Cox, R.K. Bequette, S.P. Curran, et al. 1997. Registration of Jagger wheat. Crop Sci. 37:1010. doi:10.2135/cropsci1997.0011183X0037000300 $62 \mathrm{x}$

Seifers, D.L., T.L. Harvey, J. Martin, and S.G. Jensen. 1997. Identification of the wheat curl mite as the vector of the High Plains virus of corn and wheat. Plant Dis. 81:1161-1166. doi:10.1094/ PDIS.1997.81.10.1161

Seifers, D.L., T.J. Martin, T.L. Harvey, J.P. Fellers, and J.P. Michaud. 2009. Identification of the wheat curl mite as the vector of Triticum mosaic virus. Plant Dis. 93:25-29. doi:10.1094/PDIS-93-1-0025

Seifers, D.L., T.J. Martin, T.J. Harvey, J.P. Fellers, J.P. Stack, M. Ryba-White, et al. 2008. Triticum mosaic virus: A new virus isolated from wheat in Kansas. Plant Dis. 92:808-817. doi:10.1094/PDIS-92-5-0808

Semagn, K., R. Babu, S. Hearne, and M. Olsen. 2013. Single nucleotide polymorphism genotyping using Kompetitive allele specific PCR (KASP): Overview of the technology and its application in crop improvement. Mol. Breed. 33:1-14. doi:10.1007/s11032-013-9917-x
Shevchenko, V.G., A.P. De-Millo, G.M. Razvyazkina, and E.A. Kapkova. 1970. Taxonomic bordering of closely related mites Aceria tulipae Keif. and A. tritici sp. N. (Acarina: Eriophyidae): Vectors of the onion and wheat viruses. (In Russian, with English abstract.) Zool. Zh. 49:224-235.

Skare, J.M., I. Wijkamp, J.A.M. Rezende, E.W. Kitajima, J.W. Park, B. Desvoyes, et al. 2006. A new eriophyid mite-borne membrane-enveloped virus-like complex isolated from plants. Virology 347:343-353. doi:10.1016/j.virol.2005.11.030

Slykhuis, J.T. 1955. Aceria tulipae Keifer (Acarina: Eriophyidae) in relation to the spread of wheat streak mosaic. Phytopathology 45:116-128.

Smith, C.M. 1999. Plant resistance to insects. In: J. Rechcigl and N. Rechcigl, editors, Biological and biotechnological control of insects. CRC Press, Boca Raton, FL. p. 171-205.

SoftGenetics. 2014. GeneMarker, the biologist friendly software. Release 1.9. SoftGenetics, State College, PA.

Staples, R., and W.B. Allington. 1956. Streak mosaic of wheat in Nebraska and its control. Res. Bull. 178. Univ. Nebraska, College Agric. Exp. Stn., Lincoln.

Thomas, J., Q. Chen, and L. Talbert. 1998. Genetic segregation and the detection of spontaneous wheat-alien translocations. Euphytica 100:261-267. doi:10.1023/A:1018320710129

Thomas, J.B., and R.L. Conner. 1986. Resistance to colonization by the wheat curl mite in Aegilops squarrosa and its inheritance after transfer to common wheat. Crop Sci. 26:527-530. doi:10.2135/cropsci1986.0011183X002600030019x

Thomas, J.B., and E.D.P. Whelan. 1991. Genetics of wheat curl mite resistance in wheat: Recombination of $\mathrm{Cmc1}$ with the 6D centromere. Crop Sci. 31:936-938. doi:10.2135/cropsci19 91.0011183X003100040019x

Van Ooijen, J.W. 2006. JoinMap ${ }^{\circledR}$ 4: Software for the calculation of genetic linkage maps in experimental populations. Kyazma BV, Wageningen, the Netherlands.

Wang, S., C.J. Basten, and Z.B. Zeng. 2012. Windows QTL Cartographer 2.5. North Carolina State Univ., Raleigh. http:// statgen.ncsu.edu/qtlcart/WQTLCart.htm (accessed 9 Apr. 2019).

Wegulo, S.N., G.L. Hein, R.N. Klein, and R.C. French. 2008. Managing wheat streak mosaic. Ext. EC1871. Univ. Nebraska, Lincoln.

Whelan, E.D.P., and G.E. Hart. 1988. A spontaneous translocation that transfers wheat curl mite resistance from decaploid Agropyron elongatum to common wheat. Genome 30:289-292. doi:10.1139/g88-050

Whelan, E.D.P., and J.B. Thomas. 1989. Chromosomal location in common wheat of a gene (Cmc1) from Aegilops squarrosa that conditions resistance to colonization by the wheat curl mite. Genome 32:1033-1036. doi:10.1139/g89-548 
Supplemental Table S1 Wheat accessions used for validation of two KASP-SNP markers tightly linked to Cmc4.

\begin{tabular}{|c|c|c|c|c|}
\hline & Accession name & Pedigree & 370SNP7523 \# & 370SNP1639 \# \\
\hline 1 & Atlas66 & Frondoso//Redhart 3/Noll 28 & A & A \\
\hline 2 & OK04505 & OK91724/2*Jagger & A & A \\
\hline 3 & KS05HW136-3 & KS98HW518(93HW91/93HW255)//KS98H245(IKE/TA2460//*3T200)/Trego & A & A \\
\hline 4 & $\mathrm{~T} 158$ & KS93U206/2*T81 & A & A \\
\hline 5 & KS980554-12- 9 & $2180 * \mathrm{~K} / 2163 / / ? / 3 / \mathrm{W} 1062 \mathrm{~A} * \mathrm{HVA} 114 / \mathrm{W} 3416$ & $\mathrm{~A}$ & A \\
\hline 6 & KS980512-2-2 & T67/X84W063-9-45//K92/3/SNF/4/X86509-1-1/X84W063-9-39-2//K92 & $\mathrm{A}$ & $\mathrm{A}$ \\
\hline 7 & TX04M410211 & Mason/Jagger//Ogallala & $\mathrm{A}$ & $\mathrm{A}$ \\
\hline 8 & N98L20040-44 & CS/PI467024//CS/3/SXLD/4/TAM 202/5/SXLD & A & A \\
\hline 9 & NI04420 & NE96644(=Odesskaya P/Cody)//Pavon/3*Scout 66/3/Wahoo SIB) & A & A \\
\hline 10 & Duster & W0405D/NE78488//W7469C/TX81V6187 & $\mathrm{A}$ & A \\
\hline 11 & OK02522W & Unknown & $\mathrm{A}$ & $\mathrm{A}$ \\
\hline 12 & Scout 66 & Composite of 85 selections from Scout & $\mathrm{A}$ & $\mathrm{A}$ \\
\hline 13 & AP04T8211 & W98-232/KS96WGRC38 & $\mathrm{A}$ & $\mathrm{A}$ \\
\hline 14 & HV9W96-1271R-1 & HV9W00-1551WP/KS94U326 & $\mathrm{A}$ & $\mathrm{B}$ \\
\hline 15 & NE04424 & KS92H363-2/Cougar Sib(=NE85707/TBird) & A & A \\
\hline 16 & $\mathrm{CO} 02 \mathrm{~W} 237$ & 98HW519(93HW91/93HW255)/96HW94 & $\mathrm{A}$ & $\mathrm{A}$ \\
\hline 17 & OK03825-5403-6 & $($ Custer*3/94M81)=STARS 0601W & $\mathrm{A}$ & $\mathrm{A}$ \\
\hline 18 & TX04V075080 & Jagger/TX93V5722//TX95D8905 & A & A \\
\hline 19 & SD06165 & Wesley/SD97049 & A & A \\
\hline 20 & NX03Y2489 & Bai Huo/Kanto107//Ike/3/KS91H184/3*RBL//N87V106 & A & A \\
\hline 21 & NI04427 & KS98HW22//W95-615W/N94L189 & A & A \\
\hline 22 & Endurance & HBY756A/Siouxland//2180 & A & A \\
\hline 23 & TAM 107 & TAM $105 * 4 /$ Amigo & $\mathrm{A}$ & $\mathrm{A}$ \\
\hline 24 & AP05T2413 & (KS95U522/TX95VA0011)F $1 /$ Jagger & $\mathrm{A}$ & $\mathrm{A}$ \\
\hline 25 & HV9W03-539R & KS94U275/1878//JAGGER & $\mathrm{A}$ & $\mathrm{A}$ \\
\hline 26 & CO03064 & CO970547/Prowers 99 & A & A \\
\hline 27 & TX02A0252 & TX90V6313//TX94V3724(TAM 200 BC41254-1-8-1-1/TX86V1405 & $\mathrm{A}$ & $\mathrm{A}$ \\
\hline 28 & Kharkof & Unknown & A & A \\
\hline 29 & SD06173 & Bulk02R2B & $\mathrm{A}$ & $\mathrm{A}$ \\
\hline 30 & NX04Y2107 & NW98S081/99Y1442 & A & A \\
\hline 31 & NE05548 & NE97426 (=Brigantina.2*Arapahoe)/NE98574 (=CO850267/Rawhide) & $\mathrm{A}$ & $\mathrm{A}$ \\
\hline 32 & Deliver & Yantar/2*Chisholm//Karl & $\mathrm{A}$ & $\mathrm{A}$ \\
\hline 33 & Trego & KS87H325/Rio Blanco & A & A \\
\hline 34 & HV9W03-696R-1 & N94L027/TBOLT//KS89180B & $\mathrm{A}$ & $\mathrm{A}$ \\
\hline 35 & NE05426 & W95-091 (=KS85-663-8-9//WI81-133/Thunderbird)/Akron & A & A \\
\hline
\end{tabular}




\begin{tabular}{|c|c|c|c|c|}
\hline 36 & CO03W054 & KS96HW94//Trego/CO960293 & $\mathrm{A}$ & $\mathrm{A}$ \\
\hline 37 & TX03A0148 & TX89A7137/TIPACNA & A & A \\
\hline 38 & Antelope & Pronghorn/Arlin & A & $\mathrm{A}$ \\
\hline 39 & SD03164-1 & 89118RC1-X-9-3-3/TX96D2845//Expedition & A & $\mathrm{A}$ \\
\hline 40 & NW04Y2188 & MO8/Redland//KS91H184/3*Rio Blanco & $\mathrm{A}$ & $\mathrm{A}$ \\
\hline 41 & NE05549 & NI98414(=NE90614/NE87612//NE87612)/Wesley & $\mathrm{A}$ & $\mathrm{A}$ \\
\hline 42 & OK Bullet & KS96WGRC39/ Jagger & $\mathrm{A}$ & $\mathrm{A}$ \\
\hline 43 & OK03716W & Oro Blanco/OK92403F4:11 & A & A \\
\hline 44 & OK00514-05806 & KS96WGRC39/Jagger & $\mathrm{A}$ & A \\
\hline 45 & AP06T3832 & HBK0935-29-15/KS90W077-2-2/VBF0589-1 & $\mathrm{A}$ & $\mathrm{A}$ \\
\hline 46 & HV9W02-942R & 53/3/ABL/1113//K92/4/JAG/5/KS89180B & $\mathrm{A}$ & $\mathrm{A}$ \\
\hline 47 & NE05430 & IN92823A1-1-4-5/NE92458 & $\mathrm{A}$ & $\mathrm{A}$ \\
\hline 48 & CO03W139 & CO980862/Lakin & $\mathrm{A}$ & A \\
\hline 49 & TX03A0563 & X96V107/OGALLALA & $\mathrm{A}$ & $\mathrm{A}$ \\
\hline 50 & Wesley & Plainsman V / Odesskaya 51 // Colt / Cody & $\mathrm{A}$ & $\mathrm{A}$ \\
\hline 51 & NE02533 & NE94458 (=GK-Sagvari/Colt//NE86582)/Jagger & $\mathrm{A}$ & $\mathrm{A}$ \\
\hline 52 & NE05569 & Wesley//Pronghorn/Arlin & A & $\mathrm{A}$ \\
\hline 53 & Overley & TAM $107 * 3 /$ TA 2460/ Heyne 'S'// Jagger & $\mathrm{A}$ & $\mathrm{A}$ \\
\hline 54 & OK05903C & TXGH12588-120*4/FS4//2174/3/JaggerF4:10 RC & $\mathrm{A}$ & $\mathrm{A}$ \\
\hline 55 & Century & Payne//TAM W-101/Amigo & $\mathrm{A}$ & $\mathrm{A}$ \\
\hline 56 & KS05HW15-2 & KS98HW452(KS91H153/KS93HW255)/CO960293//KS920709B-5-2(T67/X84W063-9-45//K92) & A & $\mathrm{A}$ \\
\hline 57 & T151 & T81/KS93U206 & A & $\mathrm{A}$ \\
\hline 58 & KS970093-8-9-\#1 & HBK1064-3/KS84063-9-39-3-4W//X960103 & A & $\mathrm{A}$ \\
\hline$\frac{50}{59}$ & $\mathrm{CO} 03 \mathrm{~W} 239$ & KS01-5539/CO99W165 & $\mathrm{A}$ & $\mathrm{A}$ \\
\hline 60 & TX04A001246 & TX95V4339/TX94VT938-6 & A & Missing \\
\hline 61 & Jerry & Roughrider//Winoka/NB66425/3/Arapahoe & $\mathrm{A}$ & $\mathrm{A}$ \\
\hline 62 & SD05118 & Wesley/NE93613 & $\mathrm{A}$ & $\mathrm{A}$ \\
\hline 63 & NE02558 & Jagger/Alliance & $\mathrm{A}$ & $\mathrm{A}$ \\
\hline 64 & MT0495 & MT9640/NB1133 & A & $\mathrm{A}$ \\
\hline 65 & Fuller & Jagger related & $\mathrm{A}$ & $\mathrm{A}$ \\
\hline 66 & OK03522 & N566/OK94P597 & $\mathrm{A}$ & $\mathrm{A}$ \\
\hline 67 & KS05HW121-2 & KS99-5-16(94HW98/91H153)//Stanton/KS98HW423(JAG/93HW242) & $\mathrm{A}$ & $\mathrm{A}$ \\
\hline 68 & T153 & T136/T151 & A & A \\
\hline 69 & KS970187-1-10 & TAM $107 * 2 /$ TA759//HBC197F-1/3/2145 & $\mathrm{A}$ & A \\
\hline 70 & CO03W043 & KS96HW94/CO980352 & A & $\mathrm{A}$ \\
\hline 71 & TX01V5134RC-3 & TAM 200/Jagger & $\mathrm{A}$ & A \\
\hline 72 & SD06W117 & Alice/SD00W024 & $\mathrm{A}$ & $\mathrm{A}$ \\
\hline 73 & SD05210 & SD98444/SD97060 & $\mathrm{A}$ & $\mathrm{A}$ \\
\hline
\end{tabular}




\begin{tabular}{|c|c|c|c|c|}
\hline 74 & NW03666 & N94S097KS/NE93459 & $\mathrm{B}$ & $\mathrm{B}$ \\
\hline 75 & MTS0531 & L'Govskaya167/Rampart//MT9409 (solid stem) & A & A \\
\hline 76 & Centerfield & $(\mathrm{TXGH} 12588-105 * 4 / \mathrm{FS} 4) / 2 * 2174$ & A & A \\
\hline 77 & OK04525 & FFR525W/Hickok//CoronadoF4:11 & A & A \\
\hline 78 & OK03305 & N40/OK94P455 & $\mathrm{A}$ & $\mathrm{A}$ \\
\hline 79 & MT0552 & N95L159/CDC Clair & $\mathrm{A}$ & A \\
\hline 80 & T154 & $\mathrm{T} 88 / 2180 / / \mathrm{T} 811$ & $\mathrm{~A}$ & A \\
\hline 81 & NE05496 & KS95HW62-6(=KS87H325/RIO BLANCO)/HALLAM & A & A \\
\hline 82 & TX04M410164 & MIT/TX93V5722//W95-301 & $\mathrm{A}$ & A \\
\hline 83 & SD06069 & Harry/Wesley//Jerry & $\mathrm{A}$ & A \\
\hline 84 & SD05W030 & SD98W302/NW97S186 & $\mathrm{A}$ & $\mathrm{A}$ \\
\hline 85 & Chisholm & Sturdy sib/Nicoma & $\mathrm{A}$ & A \\
\hline 86 & Guymon & Intrada/W189-163W & $\mathrm{A}$ & $\mathrm{A}$ \\
\hline 87 & OK05830 & OK93617/JaggerF6:12 & $\mathrm{A}$ & $\mathrm{A}$ \\
\hline 88 & OK02405 & Tonkawa/GK50 & $\mathrm{A}$ & $\mathrm{A}$ \\
\hline 89 & KS010957K 4 & 2145/Karl 92//KS940786-6-11 & $\mathrm{A}$ & $\mathrm{A}$ \\
\hline 90 & NE06619 & Wesley/Wahoo & $\mathrm{A}$ & $\mathrm{A}$ \\
\hline 91 & MTS04120 & L'Govskaya 167/Rampart & $\mathrm{A}$ & $\mathrm{A}$ \\
\hline 92 & TX06A001239 & Ogallala/KS94U275 & $\mathrm{A}$ & $\mathrm{A}$ \\
\hline 93 & TXHT006F8-CS06/472-STA34 & Lockett/Halberd & $\mathrm{A}$ & $\mathrm{A}$ \\
\hline 94 & MO011126 & MO94-103/Pio2552 & $\mathrm{A}$ & $\mathrm{A}$ \\
\hline 95 & $\mathrm{OH} 02-7217$ & 92118B4-2/OH561 & $\mathrm{A}$ & $\mathrm{A}$ \\
\hline 96 & MD99W483-06-9 & VA97W358/Renwood 3260 & $\mathrm{~A}$ & $\mathrm{~A}$ \\
\hline 97 & OK04507 & OK95593/Jagger//2174 & $\mathrm{A}$ & $\mathrm{A}$ \\
\hline 98 & KS020304K 3 & JAGGER/2137//KS940786-6-9 & $\mathrm{A}$ & $\mathrm{A}$ \\
\hline 99 & KS010143K-11 & TAM 400/KS950301-DD-4 & $\mathrm{A}$ & $\mathrm{A}$ \\
\hline 100 & TX05A001334 & TX87V1233-3/U1254-4-6-6//K92/3/T200*2/TA2460*2//T202 & $\mathrm{A}$ & $\mathrm{A}$ \\
\hline 101 & TX06A001376 & NE94482/TX95A1161 & $\mathrm{A}$ & $\mathrm{A}$ \\
\hline 102 & VA03W-412 & Roane/Pio2643//SS520 & A & A \\
\hline 103 & OH03-41-45 & IL91-14167/OH599 & $\mathrm{A}$ & A \\
\hline 104 & OK05312 & TX93V5919/WGRC40//OK94P549/WGRC34 & $\mathrm{B}$ & $\mathrm{B}$ \\
\hline 105 & HV9W05-881R & Mason/Ogallala-vr/Betty & A & A \\
\hline 106 & NE06436 & Wesley/OK98699 (=TAM 200/HBB313//2158) & $\mathrm{A}$ & $\mathrm{A}$ \\
\hline 107 & NW05M6011-6-1 & Nuplains/Arrowsmith & $\mathrm{A}$ & $\mathrm{A}$ \\
\hline 108 & TX06A001431 & TAM 107//TX98V3620/Ctk78/3/TX87V1233/4/N87V106//TX86V1540/T200 & A & A \\
\hline 109 & TXHT023F7-CS06/607-STA07/40 & TX99U8544/Ogallala & A & A \\
\hline 110 & AR97044-10-2 & Elkhart/AR494B-2-2 & A & A \\
\hline 111 & P02444A1-23-9 & 981129/99793//INW0301/92145 & A & A \\
\hline
\end{tabular}




\begin{tabular}{|c|c|c|c|c|}
\hline 112 & VA05W-414 & Pio25W60//VA96W-606WS(FFR555W/Coker9803//Annette)/Pio2691 & A & A \\
\hline 113 & OK05511 & TAM $110 / 2174$ & A & Missing \\
\hline 114 & SD07W041 & Falcone /SD99W042//Trego & A & A \\
\hline 115 & SD07204 & Harding//SD98243/Alliance & A & A \\
\hline 116 & NW05M6015-25-4 & NW97S186/Rio Blanco & A & A \\
\hline 117 & TXHT001F8-CS06/325-PRE07/75 & TX01M5009/Halberd & A & A \\
\hline 118 & CO04W210 & NW97S343/Akron & A & $\mathrm{A}$ \\
\hline 119 & KY96C-0769-7-3 & 2552/Roane & A & A \\
\hline 120 & P03207A1-7 & INW0304*2/RSI5//981281/3/INW0315/99794 & $\mathrm{A}$ & A \\
\hline 121 & LA01*425 & $\mathrm{P} 2571 / \mathrm{Y} 91-6 \mathrm{~B}$ & $\mathrm{~A}$ & A \\
\hline 122 & KS07HW25 & KS025580(Trego/CO960293)/KSO1HW152-6(TGO/BTY SIB) & $\mathrm{A}$ & A \\
\hline 123 & SD07220 & Tandem/Goodstreak & $\mathrm{A}$ & A \\
\hline 124 & KS010379M-2 & KS920709-B-5-2-2/TAM 400 & $\mathrm{~A}$ & $\mathrm{~A}$ \\
\hline 125 & NE06472 & $\begin{array}{l}\text { CO95043 (=Hill/PI294994//Lamar) /KS89180B-2-1(=KS8010-73/KS8010-1-4-2// } \\
\text { 107349/Karl)/NE98574 (=CO850267/Rawhide) }\end{array}$ & A & A \\
\hline 126 & Roane & VA71-54-147(CI17449)/C68-15//IN65309C1-18-2-3-2(formerly VA93-54-429) & $\mathrm{A}$ & $\mathrm{A}$ \\
\hline 127 & $\mathrm{OH} 02-12678$ & Foster/Hopewell//OH581/OH569 & $\mathrm{A}$ & A \\
\hline 128 & LA02-923 & PS8424//XY90-1B/TX851212 & $\mathrm{A}$ & A \\
\hline 129 & SD05W148-1 & SD98153/SD98W117 & $\mathrm{A}$ & A \\
\hline 130 & KS010514-9TM-10 & CM98-42/3/HBF0290/X84W063-9-39-2//ARH/4/KS940786-6-4 & $\mathrm{A}$ & A \\
\hline 131 & N02Y5117 & YUMA//T-57/3/CO850034/4/4*YUMA/ 5/KS91H184/(ARLIN S/KS91HW29//NE89526) & A & $\mathrm{A}$ \\
\hline 132 & INW0411 & 96204A1-12//Goldfield/92823A1-11(formerly P97397E1-11-2-4-1-1) & $\mathrm{A}$ & $\mathrm{A}$ \\
\hline 133 & MO040192 & IL85-2872/MO10501 & A & $\mathrm{A}$ \\
\hline 134 & NYCalR-L & Reselection of Caledonia & A & A \\
\hline 135 & KS07HW81 & KS02HW25(TGO/JGR 8W)/KS00HW114-1-1(94HW117//JGR/94HW301) & $\mathrm{A}$ & $\mathrm{A}$ \\
\hline 136 & U07-698-9 & Jagger*2/HD29 & A & $\mathrm{A}$ \\
\hline 137 & TX05V5614 & TX96V2427/TX98U8083 & A & $\mathrm{A}$ \\
\hline 138 & Branson & Pio2737W/891-4584A (Pike/FL302)(formerly M00-3701) & A & A \\
\hline 139 & IL00-8530 & IL89-1687//IL90-6364/IL93-2489 & $\mathrm{A}$ & $\mathrm{A}$ \\
\hline 140 & IL02-18228 & Pio25R26/IL9634-24437(IL90-4813/L85-3132/Ning7840)//IL95-4162 & $\mathrm{A}$ & $\mathrm{A}$ \\
\hline 141 & KS07HW117 & KS00HW151-4(94H871//VTA/94HW301)//KS98HW151-6/00HW114-1 & $\mathrm{A}$ & $\mathrm{A}$ \\
\hline 142 & NE06549 & Hallam/Wesley & $\mathrm{A}$ & $\mathrm{A}$ \\
\hline 143 & TX06A001084 & KS90WGRC10//U1275-1-11-8/TA2455/3/KS93U69/4/Ogallala/TX89V4133 & $\mathrm{A}$ & $\mathrm{A}$ \\
\hline 144 & Bess & MO11769/Madison (formerly MO981020) & A & $\mathrm{A}$ \\
\hline 145 & IL02-19463 & Patton/Cardinal//IL96-2550 & A & A \\
\hline 146 & Mocha exp. & OH489/OH490 & A & A \\
\hline 147 & Pioneer Brand 26R61 & Omega78/S76/4/Arthur71/3/Stadler//Redcoat/Wisc1/5/Coker747/6/2555sib (formerly XW663) & $\mathrm{A}$ & $\mathrm{A}$ \\
\hline 148 & NC04-15533 & NC94-6275/P86958//VA96-54-234 & $\mathrm{A}$ & $\mathrm{A}$ \\
\hline
\end{tabular}




\begin{tabular}{|c|c|c|c|c|}
\hline 149 & M03-3616-C & Hopewell/Patton & A & $\mathrm{A}$ \\
\hline 150 & W98007V1 & $\begin{array}{l}\text { F2IN82104B1-3-2(H14H15),W900003,Andy/Seneca/3/Downy/F2IN82104B1-3-2 } \\
\text { (H14H15),Williams,IN86861-8(H18)/4/NC96BGTA6 }\end{array}$ & A & A \\
\hline 151 & Arena exp. & NASW84-345/Coker9835//OH419/OH389 & A & $\mathrm{A}$ \\
\hline 152 & Coker 9553 & 89M-4035A(IL77-2656/NK79W810/Pio2580 (formerly D00*6874-2) & A & A \\
\hline 153 & VA05W-258 & VA98W-130(Savannah/VA87-54-558//VA88-54-328/Gore)//Coker9835/SS520 & A & A \\
\hline 154 & B030543 & VA93-54-429/LA85422 & $\mathrm{A}$ & $\mathrm{A}$ \\
\hline 155 & W98008J1 & IN82104B1-3-2(H14H15)/Williams, IN86861-8(H18)//NC96BGTA6 & $\mathrm{A}$ & $\mathrm{A}$ \\
\hline 156 & OK05122 & KS94U337/NE93427F4:10 & $\mathrm{A}$ & $\mathrm{A}$ \\
\hline 157 & OK06210 & KS90175-1-2/CMSW89Y271//K92/3/ABI86*3414/X86035*-BB-34//HBC 302E RC F4:9RC & A & $\mathrm{A}$ \\
\hline 158 & India exp. & KY85C-35-4/Karl/Madison & $\mathrm{A}$ & $\mathrm{A}$ \\
\hline 159 & G69202 & VA91-54-219/OH413 & A & A \\
\hline 160 & USG 3555 & VA94-52-60/Pio2643//USG3209 & $\mathrm{A}$ & $\mathrm{A}$ \\
\hline 161 & LA01138D-52 & LA841/LA422//AGS2000 & A & A \\
\hline 162 & VA05W-78 & Tribute/AGS2000 & A & A \\
\hline 163 & OK05723W & SWM866442/BettyF4:10HW & A & A \\
\hline 164 & OK06345 & FAWWON 06/2174//OK95548-26CF4:9 & A & A \\
\hline 165 & OK06319 & Enhancer/2174F4:9 & A & A \\
\hline 166 & D04*5513 & DK1551W/D94-50228 & $\mathrm{A}$ & $\mathrm{A}$ \\
\hline 167 & M04-4566 & Bradley/Roane & $\mathrm{A}$ & $\mathrm{A}$ \\
\hline 168 & $\mathrm{NC} 03-6228$ & A92-4452//NC96BGTD1sib/NC96BGTA6sib & $\mathrm{A}$ & $\mathrm{A}$ \\
\hline 169 & AR96077-7-2 & Jackson/Pio2643 & $\mathrm{A}$ & $\mathrm{A}$ \\
\hline 170 & D04-5012 & NC96BGTD1/Mason & $\mathrm{A}$ & $\mathrm{A}$ \\
\hline 171 & G59160 & T812/VA91-54-219 & $\mathrm{A}$ & $\mathrm{A}$ \\
\hline 172 & OK01420W & KS93U206/JaggerRC & $\mathrm{A}$ & $\mathrm{A}$ \\
\hline 173 & OK06528 & Vilma/Hickok//HeyneF4:9 & $\mathrm{A}$ & $\mathrm{A}$ \\
\hline 174 & OK06518 & Palma/Hickok//2174F4:9 & $\mathrm{A}$ & $\mathrm{A}$ \\
\hline 175 & KY97C-0321-02-01 & Kristy/VA94-52-25//2540 & $\mathrm{A}$ & $\mathrm{A}$ \\
\hline 176 & M04-4802 & FFR518//Elkhart/MV-18 & $\mathrm{A}$ & $\mathrm{A}$ \\
\hline 177 & AR97124-4-3 & P88288C1-6-1-2/Terra SR204 & $\mathrm{A}$ & $\mathrm{A}$ \\
\hline 178 & GA991336-6E9 & GA92432//AGS2000/Pio26R61 & Missing & $\mathrm{A}$ \\
\hline 179 & G61505 & ABI89-4584A/T814 & $\mathrm{A}$ & $\mathrm{A}$ \\
\hline 180 & OK05134 & OK97411/TX91D6825F4:10 & $\mathrm{A}$ & $\mathrm{A}$ \\
\hline 181 & OK06313 & Emma/Karl 92//2174F4:9 & $\mathrm{A}$ & $\mathrm{A}$ \\
\hline 182 & KY97C-0519-04-07 & SS555W/2540//2552 & $\mathrm{A}$ & $\mathrm{A}$ \\
\hline 183 & M04*5109 & VA94-54-479/Pio2628 & $\mathrm{A}$ & $\mathrm{A}$ \\
\hline 184 & VA04W-259 & $\begin{array}{l}\text { VA97W-533 [FFR555W/Gore//Ck9803/VA87-54-636]/NC95-11612 } \\
\text { (Stella/KS85WGRC01//C8433/3/C8629/FL7927) }\end{array}$ & A & $\mathrm{A}$ \\
\hline
\end{tabular}




\begin{tabular}{|l|l|l|l|}
\hline 185 & MD01W233-06-1 & McCormick/Choptank & A \\
\hline 186 & GA991209-6E33 & GA901146/GA96004//AGS2000 & A \\
\hline 187 & G41732 & T814/L900819 & A \\
\hline 188 & OK06848W & OK94P461/Oro BlancoF6:11 & A \\
\hline 189 & W06-202B & Ashland/Hopewell//OH546/L930605 & A \\
\hline 190 & TAM 110 & TAM 105*4/Amigo*5//Largo & A \\
\hline 191 & LA99005UC-31-3-C & Pio2548/Coker9835(LA90144B16-3-2)//AGS2000 & A \\
\hline 192 & Siyang936 & unknown & A \\
\hline
\end{tabular}

\# A refers to the allele same as Jerry and B refers to the allele same as OK05312

Supplemental Table S2 Putative gene annotated between two flanking markers 370SNP7523 and 370SNP1639 in A. Tauschii genome reference and their corresponding locations in Chinese Spring wheat reference

\begin{tabular}{|c|c|c|c|c|}
\hline $\begin{array}{l}\text { Gene names in } A \text {. } \\
\text { Tauschii }\end{array}$ & $\begin{array}{l}\text { Start } \\
\text { position } \\
\text { (bp) }\end{array}$ & $\begin{array}{l}\text { End } \\
\text { position } \\
\text { (bp) }\end{array}$ & $\begin{array}{l}\text { Homoeologous gene in } \\
\text { wheat }\end{array}$ & Annotated Gene function \\
\hline SNP7523 & $2,101,778$ & & & \\
\hline AET6Gv20009000 & $2,126,648$ & $2,137,694$ & TraesCS6D01G005100.1 & RING/U-box superfamily protein \\
\hline AET6Gv20009100 & $2,134,894$ & $2,140,474$ & TraesCS6D01G005200.1 & Protein disulfide-isomerase \\
\hline AET6Gv20009400 & $2,222,355$ & $2,234,422$ & TraesCS6D01G005500.1 & transmembrane protein, putative (DUF594) \\
\hline AET6Gv20009600 & $2,252,735$ & $2,266,164$ & TraesCS6D01G005600.1 & E3 ubiquitin-protein ligase \\
\hline AET6Gv20009700 & $2,271,658$ & $2,515,586$ & TraesCS6D01G005700.1 & casein kinase \\
\hline AET6Gv20010000 & $2,302,974$ & $2,312,934$ & TraesCS6D01G005600.1 & E3 ubiquitin-protein ligase \\
\hline AET6Gv20010100 & $2,340,695$ & $2,341,333$ & TraesCS6B01G000500.1 & casein kinase \\
\hline AET6Gv20010300 & $2,346,972$ & $2,347,637$ & TraesCS6B01G000500.1 & casein kinase \\
\hline AET6Gv20010400 & $2,474,438$ & $2,474,650$ & No match sequence & \\
\hline AET6Gv20010600 & $2,493,553$ & $2,493,765$ & No match sequence & \\
\hline AET6Gv20010900 & $2,569,924$ & $2,578,877$ & TraesCS6A01G003700.1 & Kinesin-like protein \\
\hline AET6Gv20011100 & $2,587,939$ & $2,591,022$ & TraesCS6A01G003800.1 & NAC domain protein \\
\hline AET6Gv20011200 & $2,612,025$ & $2,613,852$ & TraesCS6D01G006200.1 & Pollen Ole e 1 allergen/extensin \\
\hline AET6Gv20011500 & $2,734,235$ & $2,736,522$ & TraesCS6A01G004200.1 & F-box protein \\
\hline AET6Gv20011600 & $2,737,378$ & $2,739,423$ & TraesCS6D01G006400.1 & F-box protein \\
\hline AET6Gv20011900 & $2,760,819$ & $2,777,267$ & TraesCS6D01G006500.1 & Terpene cyclase/mutase family member \\
\hline AET6Gv20012000 & $2,806,344$ & $2,817,844$ & TraesCS6D01G006600.1 & Ankyrin repeat family protein \\
\hline
\end{tabular}




\begin{tabular}{|c|c|c|c|c|}
\hline AET6Gv20012200 & $2,823,470$ & $2,825,202$ & TraesCS6D01G007000.1 & Patatin \\
\hline AET6Gv20012500 & $2,842,026$ & $2,844,827$ & TraesCS6D01G007100.1 & DAG, chloroplastic \\
\hline AET6Gv20012700 & $2,859,273$ & $2,860,709$ & TraesCS6D01G007400.1 & Pathogen-related protein \\
\hline AET6Gv20012800 & $2,861,373$ & $2,866,389$ & TraesCS6B01G010200.1 & Leucine-rich repeat receptor-like protein kinase family protein \\
\hline AET6Gv20013100 & $2,895,314$ & $2,889,864$ & TraesCS6D01G007600.1 & Protein ENHANCED DISEASE RESISTANCE 2-like \\
\hline AET6Gv20013200 & $2,935,195$ & $2,932,530$ & TraesCS6D01G007700.1 & Ubiquitin carboxyl-terminal hydrolase 2 \\
\hline AET6Gv20013300 & $2,941,897$ & $2,942,443$ & TraesCS3D01G425700.1 & receptor kinase 1 \\
\hline AET6Gv20013400 & $2,960,426$ & $2,960,977$ & TraesCS6B01G010700.1 & Disease resistance protein (TIR-NBS-LRR class) \\
\hline AET6Gv20013600 & $2,987,461$ & $2,989,799$ & TraesCS6D01G008000.1 & T-complex protein 1 subunit theta \\
\hline AET6Gv20013700 & $3,045,249$ & $3,051,133$ & TraesCS6D01G008100.1 & Flavonoid 3'-hydroxylase \\
\hline AET6Gv20013800 & $3,073,042$ & $3,070,638$ & TraesCS6D01G008200.1 & O-methyltransferase \\
\hline AET6Gv20014000 & $3,218,829$ & $3,190,014$ & TraesCS6D01G008300.1 & Senescence-associated protein DIN1 \\
\hline AET6Gv20014300 & $3,203,115$ & $3,206,167$ & No match sequence & \\
\hline AET6Gv20014600 & $3,234,818$ & $3,231,797$ & TraesCS6D01G008500.1 & Rhodanese-related sulfurtransferase \\
\hline AET6Gv20014700 & 3,236314 & $3,235,121$ & TraesCS6D01G008600.1 & Rhodanese-related sulfurtransferase \\
\hline AET6Gv20015000 & $3,251,168$ & $3,247,763$ & TraesCS6D01G009000.1 & Red chlorophyll catabolite reductase \\
\hline AET6Gv20015200 & $3,352,158$ & $3,357,710$ & TraesCS6D01G009100.1 & $60 \mathrm{kDa}$ chaperonin \\
\hline AET6Gv20015400 & $3,361,316$ & $3,363,469$ & TraesCS6D01G009200.1 & Serine/threonine-protein kinase WNK1 \\
\hline AET6Gv20015500 & $3,368,459$ & $3,365,583$ & TraesCS6D01G009300.2 & Zinc finger (C3HC4-type RING finger) family protein \\
\hline AET6Gv20015700 & $3,373,110$ & $3,372,408$ & TraesCS6D01G009400.1 & Ankyrin repeat domain-containing protein $\mathrm{CP} 77$ \\
\hline
\end{tabular}

